\title{
The impacts of value, disconfirmation and satisfaction on loyalty: Evidence from international higher education setting
}

\section{Hiep-Hung Pham, Sue Ling Lai and Quan-Hoang Vuong}

Relationships with international students can be beneficial to higher education in terms of financial and human resources. For this reason, establishing and maintaining such relationships are usually pre-eminent concerns. In this study, we extended the application of the disconfirmation expectation model by incorporating components from subjective task value to predict the loyalty of international students toward their host countries. On a sample of 410 Vietnamese students enrolled in establishments of higher education in over 15 countries across the globe, we employed structural equation model to construct the conceptual model. Our empirical findings revealed that while the roles of satisfaction and disconfirmation are still important as direct and indirect antecedents of international student loyalty, its most powerful predictors are the three components of subjective task value: attainment, utility and intrinsic. These insights result in a number of implications for actors on the higher education scene, such as heads of institutions and policy makers.

Keywords: international student, loyalty, value, disconfirmation, satisfaction JEL Classifications: I21, I25, I26

CEB Working Paper No 17/035

December 2017 


\title{
The impacts of value, disconfirmation and satisfaction on loyalty: Evidence from international higher education setting
}

\author{
Hiep-Hung, Pham ${ }^{1,2}$, Sue Ling Lai ${ }^{1}$, Quan-Hoang Vuong ${ }^{2,3}$ \\ ${ }^{1}$ Department of International Business Administration, Chinese Culture University, \\ Taiwan (ROC) \\ ${ }^{2}$ Centre for Interdisciplinary Social Research, Western University, Hanoi, Vietnam \\ ${ }^{3}$ Centre Emile Bernheim, Université Libre de Bruxelles, Brussels 1050, Belgium
}

\begin{abstract}
Relationships with international students can be beneficial to higher education in terms of financial and human resources. For this reason, establishing and maintaining such relationships are usually pre-eminent concerns. In this study, we extended the application of the disconfirmation expectation model by incorporating components from subjective task value to predict the loyalty of international students toward their host countries. On a sample of 410 Vietnamese students enrolled in establishments of higher education in over 15 countries across the globe, we employed structural equation model to construct the conceptual model. Our empirical findings revealed that while the roles of satisfaction and disconfirmation are still important as direct and indirect antecedents of international student loyalty, its most powerful predictors are the three components of subjective task value: attainment, utility and intrinsic. These insights result in a number of implications for actors on the higher education scene, such as heads of institutions and policy makers.
\end{abstract}

Keywords: international student, loyalty, value, disconfirmation, satisfaction

JEL Classification: I21, I25, I26 


\section{Introduction}

Retaining and maintaining enduring relationships with international students have been regarded as strategically goals by higher education institutions across the world. First, international students nowadays have become an important financing source (Marginson, 2007; Slaughter \& Cantwell, 2012). At the national level, cross-border education has become a key export industry for several countries. For instance, in the 2015-2016 academic years, international students contributed \$20.3 billion to the Vietnamese economy; the highest ever recorded revenue in the history of that country's education sector. International higher education, indeed, has become the third most important export sector of Australia, just behind two mining industries: iron and coal (University Australia, 2016). At the institutional level, as universities across the world are falling victim to cuts in government subsidies, they are seeking additional inflow of revenue from foreign markets (Ehrenberg, 2012; Healey, 2008). Cantwell (2015) reported that universities, especially public ones, are becoming more and more dependent on tuition as a source of income. As a consequence, they are targeting self-paid students to generate additional income. Second, international students are increasingly regarded as potential qualified workers for host countries (Douglass \& Edelstein, 2009). A problem common to more developed countries in recent times is the shortage of high-qualified manpower in science, technology, engineering and math (STEM) majors (Vuong, 2017; Vuong 2018). For instance, a report issued by the American Action Forum (Varas, 2016) predicted that by 2024 the US would have a lack of 1.1 million STEM personnel, of which 100,000 could be supplied by foreign citizens.

Similar phenomena also have been observed in other developed countries such as Australia (Marginson, Tytler, Freeman \& Roberts, 2013). However, despite the significant role of international students, there is little understanding of the mechanism by which "loyalty" — a personal attachment formed between a customer and a goods or service provider - to their educational institution is established. The majority of the extant literatures concerning students, from a marketing perspective, seem to over-emphasize domestic students while overlooking international ones (Pham \& Lai, 2016).

According to previous studies (e.g., Field, 1999; Hechanova-Alampay, Beehr, Christiansen, \& Van Horn, 2002; Khawaja \& Dempsey, 2008), there are considerable differences between domestic and international students in terms of psychology and 
behavior. This might stem from the fact that each category of students has different inherent concerns. Khawaja \& Dempsey (2008) found that, compared to domestic students, international students had less social support and had a tendency to be more isolated due to their spatial distance from home. This led to their reluctance or unawareness to use supporting services provided by universities, which in turn influenced their satisfaction.

As such, to fill the gap between the extant literatures and the loyalty problem mentioned above, the purpose of this study is to investigate international student loyalty to the establishments in which they enrolled, as well as factors influencing this attachment through a sample of Vietnamese students currently studying abroad in over 15 countries. Specifically, we aim to investigate the impacts of direct and indirect antecedents of student loyalty in the international higher education setting. By employing two well-established models in behavioral science, the expectation disconfirmation model (Oliver, 1980) and the expectancy-value model of achievement motivation (Eccles, 1987), we endeavor to shed light on international students' loyalty.

\section{Literature Review}

\subsection{Expectation disconfirmation model}

The expectation disconfirmation model was developed as a powerful framework in relationship marketing for explaining the post-purchase behavior and process of customers (Oliver, 1980). According to this model, satisfaction is the most influential direct determinant of customer loyalty. Meanwhile, disconfirmation, which is defined as "the difference between a consumer's pre-purchase expectations and the post-purchase performance of a product or service" (Liao, Chen \& Yen, 2007, p. 2807), would act as a direct antecedent of satisfaction and thus an indirect antecedent of customer loyalty. A positive disconfirmation means the customers tend to be satisfied, in which case a higher degree of customer loyalty would be more likely. That is, there would be a higher likelihood to repurchase and higher positive emotion toward the incumbent service or product providers, and vice versa.

In the higher education setting, a number of prior endeavors have employed the expectation disconfirmation model in order to examine domestic student loyalty (e.g., Appleton-Knapp \& Krentler, 2006; Athiyaman, 1997). It was expected that the expectation disconfirmation model would be suitable to shed light on international 
student loyalty. However, the limitation of this model is that it overlooks the role of value. Value, indeed, should be regarded as a central construct in relationship marketing in general (Grönroos \& Voima, 2013; Ravald \& Grönroos, 1996) and in higher education student loyalty particularly (Alves, 2011). To fill this void, we incorporated subjective task value to the expectation disconfirmation model to achieve our research goals.

\subsection{Subjective task value}

Value is an important component of relationship marketing (Grönroos \& Voima, 2013; Ravald \& Grönroos, 1996). Along with the increase of value added to the service, suppliers aim to raise satisfaction among their customers, and subsequently obtain customer loyalty.

For higher education, learning is the main value of the co-creation process, rather than teaching. Within this, lecturers and students within the service-scapeincluding library, classroom, learning management system and so forth-use their own resources to participate in the co-creation of learning (Edvardsson, Tronvoll \& Gruber, 2010). Therefore, value is a factor that should not be neglected when analyzing higher education as a service.

There are different ways to define the concept of value. For instance, Jones, Reynolds, \& Arnold (2006) divided value into two dimensions, i.e., utilitarian value and hedonic value. While the former focuses on the functional benefits and sacrifices that a consumer perceives from a product or service; the latter centers on overall judgment of the consumer while he or she consumes the product or service.

Within the sector of education, there is a stream of extant literature that regards value from the perspective of the expectancy-value model of achievement motivation, e.g., in math study (Wigfield \& Eccles, 1989); e-learning (Chiu \& Wang, 2008); graduate education of female students (Battle \& Wigfield, 2003); adult education (Gorges \& Kandler, 2012). Thus, in regard to the expectancy-value model of achievement motivation, Chiu \& Wang (2008) stated, “individuals' performance, persistence, and choice are directly predicted by their expectancies of success on the tasks and the subjective task value that represents success" (p. 195).

In this study, we use the same conceptualization of value to predict the intention and choice of international students. Specifically, we follow Battle \& Wigfield's (2008) work to examine three components of value from the expectancymodel of achievement motivation, including: attainment value ('importance of doing 
well on a given task'), utility value ('how task completion facilitates future goals') and intrinsic value ('the enjoyment one gains from doing the task') (p. 58). In the international higher education setting, attainment value may refer to the actual knowledge, skill or experience that one obtains after completing his or her degree overseas. Utility value may refer to the extent to which the degree from international institutions may help its holder to get promoted, to get a higher salary or to find a good job. Intrinsic value may imply the enjoyment of study and life within the campus as well as in the host country.

\section{The Conceptual Framework and Hypothesis Development}

The conceptual framework guiding this study is presented in Figure 1. First, we suggest that loyalty, which is conceptualized from an attitudinal perspective (Backman \& Crompton, 1991; Reichheld, 2003) is the dependent variable. The two factors of the expectation disconfirmation model, satisfaction and disconfirmation, are proposed as direct and indirect determinants, respectively (Oliver, 1980).

Meanwhile, we foresee that value would have a direct influence on disconfirmation and satisfaction, as well as loyalty. In this study, value is considered from a subjective task point of view, which involves three sub-components: utility and intrinsic value (Battle \& Wigfield, 2003). It is hypothesized that value has a direct impact on the three other variables, i.e., disconfirmation, satisfaction (Ha \& Janda, 2008), and loyalty (Parasuraman \& Grewal, 2000) that are included in this study. Given the above, we propose the following five hypotheses:

H1. Disconfirmation has a positive impact on satisfaction.

H2. Satisfaction has a positive impact on loyalty.

H3. Value has a positive impact on disconfirmation.

H4. Value has a positive impact on satisfaction.

H5. Value has a positive impact on loyalty. 


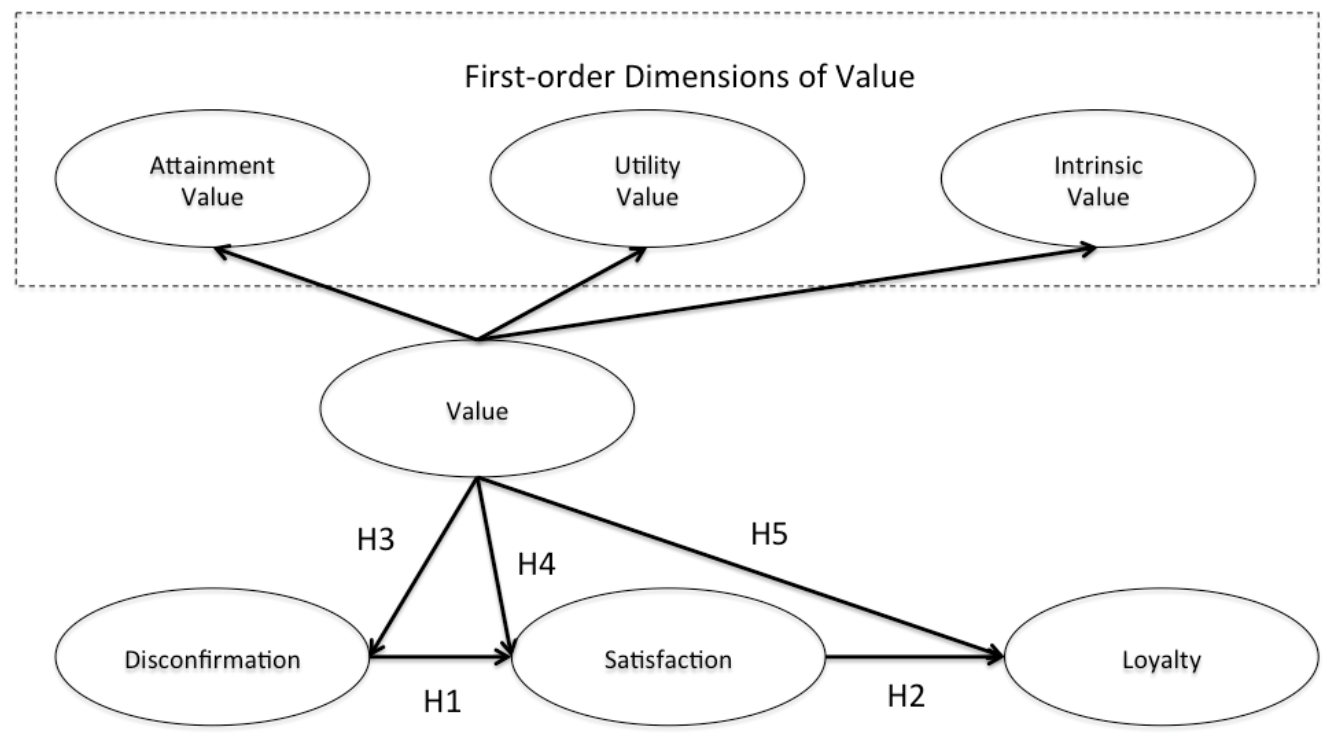

Figure 1. The conceptual framework

\section{Research method}

\subsection{Questionnaire and Measurement}

The survey questionnaire is composed of two sections:

- The first section collects demographic information, such as age, gender, the current host country, or major, etc.

- In the second section, we focus on measuring items associated with the hypotheses. All questionnaire items employed in this study are from prior well-established measurements, with necessary adjustments to fit the context of international higher education. Likert scales of 5 or 7 are used to measure these items.

\subsection{Pilot test}

Two scholars, one majoring in education and another majoring in management, were invited to read and revise the questionnaires. This step was taken to ensure the face validity of the measurements. On the basis of these scholars' readings, further revisions of the terminology were made.

\subsection{Participants}

The conceptual framework proposed in this study was assessed in the context of international higher education. Our selected sample is Vietnamese overseas students. According to Choudaha \& Kono (2012), Vietnam is one of the countries with the highest growth in numbers of students enrolled in foreign educational 
establishments. In 2016, Vietnam had around 130,000 students across the globe (Ha Phuong, 2016), a 16.5\% increase over 2012. Traditionally, Vietnamese students go abroad with scholarships and fellowships funded by the host countries' government or the Vietnamese government (Pham \& Lai, 2016). However, thanks to the growing number of middle-income families, and the low capacity of the domestic higher education system (in both quantitative and qualitative dimensions), more and more families are willing to pay for foreign diplomas of higher education and thus encourage their children to go abroad. According to Ha Phuong (2016), Japan shares the biggest part with $29 \%$ of the 130,000 Vietnamese students abroad. This is followed by Australia (24\%), the US (22\%) and China (10\%).

\subsection{Data collection}

An online survey was selected as the method to obtain data. Due to the proliferation of the Internet, online surveying has been increasingly employed by both researchers and industry consultants (Bhattacherjee, 2001). Data collection was undertaken during five months from December 2015 to April 2016. A solicitation message was sent through Facebook to 2000 people randomly selected from member lists of some Facebook-based groups of Vietnamese students in different countries. First, the reader was asked if he or she had an intention to undertake further formal education (including bachelor's degree, master's, doctorate or post-doctoral fellowship) in the near future. Only in the case of a positive answer was that the reader invited to click through the URL to answer the questionnaire.

The sampling procedure yielded a total of 461 responses out of the 2000 message invitations sent, equivalent to a response rate of 23.05 percent. Among these 461 responses, 51 were eliminated due to incomplete answers. The sample covers students studying in 15 countries across the world. Table 1 represents the profiles of our respondents. 
Table 1. Profile of Respondents

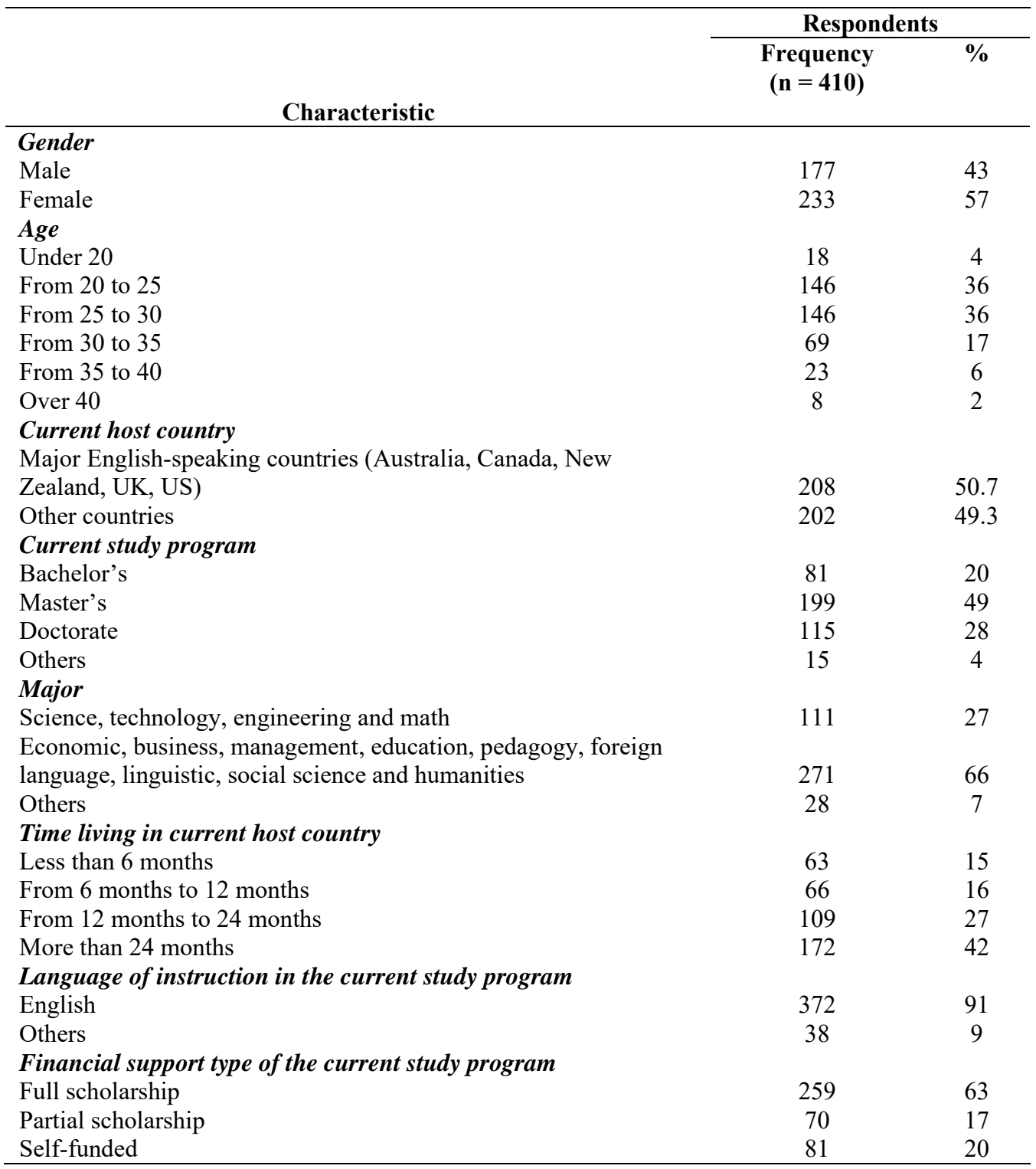

\section{Results}

\subsection{Measurement validation}

First, confirmatory factor analysis (CFA) was employed to verify the measurements. All results of multiple fit indices, including chi-square, degree of freedom, goodness of fit (GFI), adjusted goodness of fit (AGFI), normed fit index (NFI), comparative fit index (CFI), root mean square error of approximation (RMSEA), and Bentler comparative fit index (BCFI) obtained from CFA satisfied the rule of thumb. Table 2 shows the details of our multiple fit indices.

To address the issue of convergent validity, we examined the items' factor 
loadings, construct reliability (CR), and average variance extracted (AVE).

As indicated in Table 3 and 4, all the above indicators were satisfied: all factors loadings for questionnaire items, except LOY1, are above 0.7 and significant in a $t$-test; all CRs and AVEs are above their correspondent thresholds: 0.7 and 0.5, respectively.

Finally, we address the issue of discriminant validity through comparing AVE scores and the square of parameters estimated among the latent variables. As the results show that all AVE scores are higher than the square parameters, we conclude that the scale of our study has a certain amount of discriminant validity.

Table 2: Results of multiple fit indices

\begin{tabular}{lll}
\hline Index & Result & Acceptable level \\
\hline Chi-square & 180.96 & - \\
Degree of freedom & 104 & $<$ \\
Chi-square/ Degree of freedom & 1.74 & $>0.9$ \\
GFI & 0.95 & $>0.8$ \\
AGFI & 0.92 & $>0.9$ \\
NFI & 0.95 & $<0.08$ \\
RMSEA & 0.04 & $>0.9$ \\
BCFI & 0.98 & \\
\hline
\end{tabular}

Table 3. Results of factor loading for Confirmatory Factor Analysis

\begin{tabular}{|c|c|c|}
\hline Items & Factor loading & $t$ statistic \\
\hline \multicolumn{3}{|l|}{ Attainment value } \\
\hline $\begin{array}{l}\text { ATV1: You think staying in current host country for further } \\
\text { study make you a more knowledgeable person }\end{array}$ & 0.84 & 47.63 \\
\hline $\begin{array}{l}\text { ATV2: You think staying in current host country for further } \\
\text { study offers an opportunity for fulfilling achievement }\end{array}$ & 0.90 & 64.69 \\
\hline $\begin{array}{l}\text { ATV3: You think staying in current host country for further } \\
\text { study confirms your competence }\end{array}$ & 0.83 & 45.68 \\
\hline \multicolumn{3}{|l|}{ Utility Value } \\
\hline $\begin{array}{l}\text { UTV1: You think what you obtain by staying in current host } \\
\text { country for further study is useful for your promotion }\end{array}$ & 0.82 & 34.72 \\
\hline $\begin{array}{l}\text { UTV2: You think what you obtain by staying in current host } \\
\text { country for further study is useful for getting salary raise }\end{array}$ & 0.77 & 28.85 \\
\hline $\begin{array}{l}\text { UTV3: You think what you obtain by staying in current host } \\
\text { country for further study is useful for you to get a job }\end{array}$ & 0.72 & 24.79 \\
\hline \multicolumn{3}{|l|}{ Intrinsic Value } \\
\hline $\begin{array}{l}\text { INV1: You think staying in current host country for further } \\
\text { study is interesting }\end{array}$ & 0.89 & 59.36 \\
\hline $\begin{array}{l}\text { INV2: You think staying in current host country for further } \\
\text { study is enjoyable }\end{array}$ & 0.90 & 62.75 \\
\hline $\begin{array}{l}\text { INV3: You think staying in current host country for further } \\
\text { study is not fun (reversed code) }\end{array}$ & 0.76 & 32.85 \\
\hline \multicolumn{3}{|l|}{ Disconfirmation } \\
\hline $\begin{array}{l}\text { DIS1: Your experience with studying at the current university } \\
\text { and living in the current host country is worse than what you } \\
\text { expected before (reverse code) }\end{array}$ & 0.88 & 37.37 \\
\hline $\begin{array}{l}\text { DIS2: The education provided by your current university and } \\
\text { the living conditions and environments provided by your }\end{array}$ & 0.88 & 37.50 \\
\hline
\end{tabular}


current host country are better than what you expected before

\section{Satisfaction}

Overall, how do you feel about the service provided to you by your current university and the life in the current host

country?

SAT1: Satisfied $\quad 0.85 \quad 38.79$

$\begin{array}{lll}\text { SAT2: Pleased } & 0.83 & 36.87\end{array}$

$\begin{array}{lll}\text { SAT3: Contented } & 0.67 & 21.50\end{array}$

Loyalty

LOY1: You will say positive things about universities in the $\quad 0.69 \quad 23.21$

current host country to other people

LOY2: You will recommend the current host country to $\quad 0.89 \quad 46.14$

someone seeking your advice for education service

LOY3: You will encourage your friends/relatives to study in $\quad 0.79 \quad 33.41$

the current host country

Table 4. Convergent and Discriminant Validity

\begin{tabular}{lllllllll}
\hline Construct & CR & AVE & \multicolumn{7}{c}{ Factor correlation } \\
\cline { 4 - 8 } & & & ATV & UTV & INV & DIS & SAT & LOY \\
\hline ATV & 0.89 & 0.73 & 1 & & & & & \\
UTV & 0.81 & 0.59 & 0.69 & 1 & & & & \\
INV & 0.89 & 0.73 & 0.60 & 0.56 & 1 & & & \\
DIS & 0.87 & 0.77 & 0.39 & 0.37 & 0.41 & 1 & & \\
SAT & 0.83 & 0.62 & 0.38 & 0.39 & 0.39 & 0.62 & 1 & \\
LOY & 0.84 & 0.63 & 0.45 & 0.39 & 0.54 & 0.52 & 0.49 & 1 \\
\hline
\end{tabular}

\section{2. $\quad$ Structural Model and Hypothesis Testing}

Figure 2 and Table 5 show the results of the structural equation model. In general, all endogenous constructs are explainable through the exogenous constructs selected in our conceptual model. Specifically, $40.97 \%$ of the variance of loyalty is predicted in this model. In parallel, $42.47 \%$ and $25.48 \%$ of the variance of satisfaction and disconfirmation are explained in this model, respectively.

Regarding path analyses, as shown in Figure 2 and Table 5, all five hypotheses in this study are supported by our empirical analysis of structural equation model. In particular, disconfirmation has a direct impact on satisfaction $(\beta=0.50, t=9.41)$. Subsequently, satisfaction influences directly on loyalty $(\beta=0.28, t=8.00)$. Therefore, Hypotheses 1 and 2 are supported. Regarding the role of value, all liaisons starting from value and ending at disconfirmation $(\beta=0.50, t=10.71)$, satisfaction $(\beta=0.23$, $t=3.90)$, and loyalty $(\beta=0.44, t=8.00)$ are statistically significant. Thus, Hypotheses 3 , 4 , and 5 are all supported.

Table 5. Results of Structural Equation Model

Dependent variable: Disconfirmation t value

Hypothesis 


\begin{tabular}{|c|c|c|c|}
\hline Value & 0.50 & 10.71 & H3 supported \\
\hline $\mathrm{R}^{2}$ & $25.48 \%$ & & \\
\hline \multicolumn{4}{|c|}{ Dependent variable: Satisfaction } \\
\hline Value & 0.23 & 3.90 & H4 supported \\
\hline Disconfirmation & 0.50 & 9.41 & H1 supported \\
\hline $\mathrm{R}^{2}$ & $42.47 \%$ & & \\
\hline \multicolumn{4}{|c|}{ Dependent variable: Loyalty } \\
\hline Value & 0.44 & 8.00 & H5 supported \\
\hline Satisfaction & 0.28 & 5.06 & H2 supported \\
\hline $\mathrm{R}^{2}$ & $40.97 \%$ & & \\
\hline
\end{tabular}

As mentioned above, in this study we regard value as a second-order construct with three first-order variables, i.e., attainment value, utility value and intrinsic value. As all second-order factor loadings are statistically significant as shown in Figure 2, we conclude that value is best divided into the three sub-constructs.

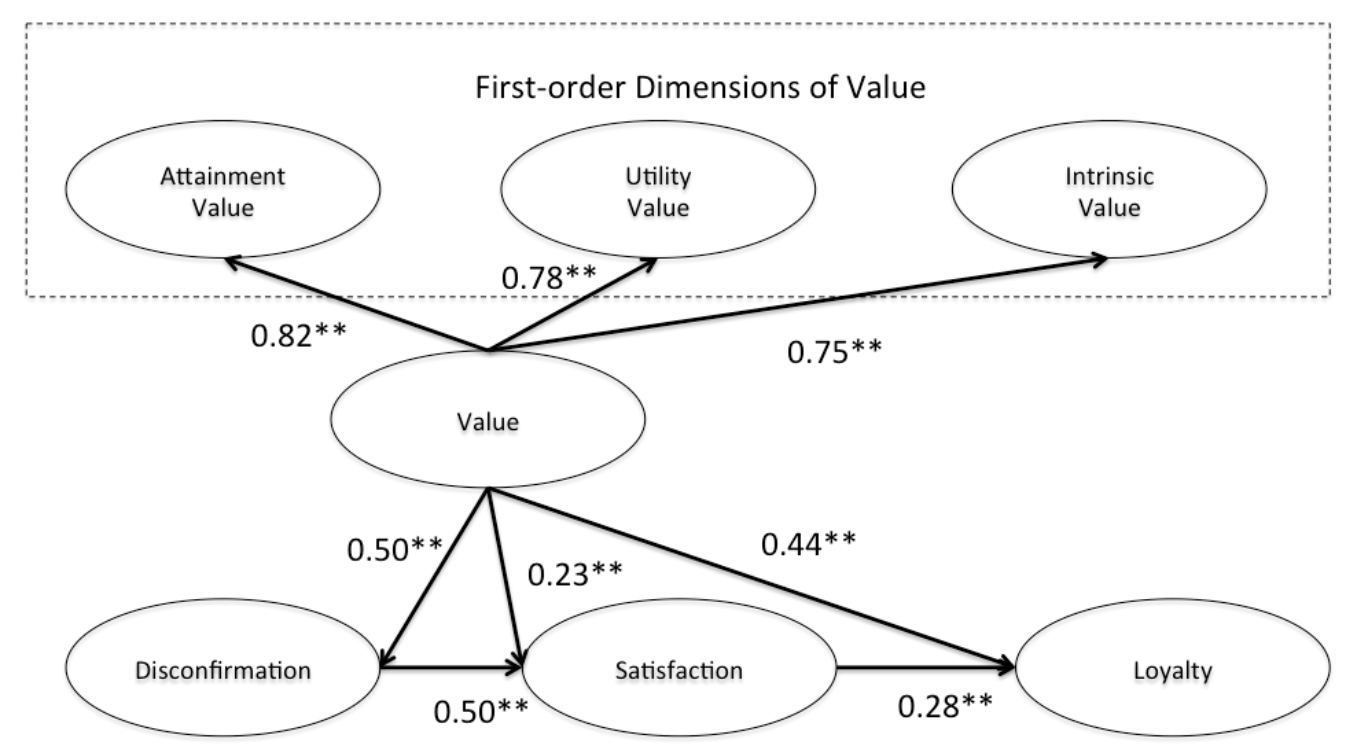

Figure 2. Standardized solution of Structural Equation Model

\subsection{Total effects of direct and indirect antecedents of international student loyalty}

In Table 6, we estimate the total impacts from direct and indirect antecedents to loyalty. Total effect here is equal to the sum of direct and indirect effect. Among the three antecedents of loyalty, value plays the role of both direct and indirect predictor of loyalty. Meanwhile, disconfirmation only has an indirect effect on loyalty and satisfaction has only direct effect. Overall, as represented in Table 6, value is the most important determinant in formulating attitudinal loyalty (total effect of 0.57 ), followed by satisfaction (0.28), disconfirmation (0.14). 
Regarding the three first-order sub-constructs of value (attainment value, utility value and intrinsic value), we multiply the second-order factor loadings of value and its sub-constructs with the total effect of value on loyalty, we will obtain the effects of each sub-construct on value. Hence, the effects of attainment value, utility value and intrinsic value on loyalty are $0.47(=0.82 * 0.57), 0.44(=0.78 * 0.57)$ and $0.42(=0.75 * 0.57)$, respectively.

Table 6. Direct, indirect and total effects of value, disconfirmation, satisfaction on loyalty

\begin{tabular}{|c|c|c|c|}
\hline Antecedent & $\begin{array}{c}\text { Direct Effect } \\
\text { (Route \& } \\
\text { Magnitude of the } \\
\text { effect) }\end{array}$ & $\begin{array}{c}\text { Indirect Effect } \\
\text { (Route } \& \\
\text { Magnitude of the effect) }\end{array}$ & Total Effect \\
\hline \multirow[t]{2}{*}{ Value } & \multirow[t]{2}{*}{$\begin{array}{l}\text { Value - Loyalty } \\
(0.44)\end{array}$} & $\begin{array}{l}\text { Value - Satisfaction - Loyalty } \\
(0.23 * 0.28)\end{array}$ & \multirow[t]{2}{*}{0.57} \\
\hline & & $\begin{array}{l}\text { Value - Disconfirmation - } \\
\text { Satisfaction - Loyalty } \\
(0.50 * 0.50 * 0.28)\end{array}$ & \\
\hline Disconfirmation & - & $\begin{array}{l}\text { Disconfirmation }- \text { Satisfaction - } \\
\text { Loyalty }(0.50 * 0.28)\end{array}$ & 0.14 \\
\hline Satisfaction & $\begin{array}{l}\text { Satisfaction - } \\
\text { Loyalty } \\
(0.28)\end{array}$ & - & 0.28 \\
\hline
\end{tabular}

\section{Discussion and Conclusion}

Student loyalty has been considered as an important issue within the fields of educational management and educational marketing. Contrary to abundant prior investigations of domestic student loyalty, there have been few studies of their international counterparts despite the benefits that this cluster of students brings to higher education providers. This study fills this gap by examining the antecedents of loyalty of 410 Vietnamese students studying in 15 countries across the world. Specifically, this study incorporates the components from two dominant models, i.e., disconfirmation-expectation model and expectancy-value model of achievement motivation, to explain international student loyalty.

\subsection{Summary of results}

Our empirical findings corroborate the five hypotheses stated at the outset of this study. Specifically, we found that disconfirmation has a positive indirect impact on loyalty through the full mediating role of satisfaction. In parallel, there are three direct routes starting from value and ending at disconfirmation, satisfaction and 
loyalty. Among the three antecedents of loyalty, value has been found to be the most influencing driver, followed by satisfaction and disconfirmation.

Regarding the conceptualization of value, it has been established that, within the framework of this study, value is best divided into three sub-constructs, i.e. attainment value, utility value and intrinsic value. Among these three sub-constructs, our empirical results indicated that attainment value is the most influential component, followed by utility value and intrinsic value.

\subsection{Theoretical Implications}

The data collected in this project confirm the suitability of employing the disconfirmation-expectation model (Oliver, 1980) within the context of higher education (e.g., Appleton-Knapp \& Krentler, 2006; Athiyaman, 1997; Pham \& Lai, 2016). However, as this study revealed that satisfaction is not the most influencing determinant of loyalty, it reconfirms the assertion of previous authors including Kumar, Dalla Pozza \& Ganesh (2013). In their review article, these authors argued that satisfaction is not necessarily the best predictor of (affective) loyalty.

Indeed, as shown above, it is found that value is the most influential antecedent of loyalty in the international higher education setting. This finding is, in fact, in line with a number of previous studies in different settings, e.g., tourism (Pandža Bajs, 2015), social media (Hu, Kettinger \& Poston, 2015), financial service (Floh, Zauner, Koller \& Rusch, 2014). Among the three sub-constructs of value, attainment value is found to be the most important factor contributing to loyalty, followed by utility value and intrinsic value. Thus, this is somewhat different from the findings of Chiu \& Wang (2008). According to Chiu \& Wang, intrinsic value is the most important factor, while utility value is the least important and attainment value stands in the middle. A plausible reasoning for this difference may be the different settings employed in the two studies. The setting in Chiu \& Wang's work was a webbased learning system and the subjects were adult students, while in our case the setting is international higher education and the subjects are full-time students. In Chiu \& Wang's section on the limitations of their study, the authors also argued that there might be differences between part-time and full-time students regarding the mechanism leading to loyalty. Our study, indeed, verifies what Chiu \& Wang (2008) predicted previously. 


\subsection{Practical Implications}

Our findings have implications for policy makers and managers of international education programs in higher education institutions. First, this study verified the robustness of the disconfirmation expectation model in general settings (Oliver, 1980). Thus, in higher education in particular (Appleton-Knapp \& Krentler, 2006; Athiyaman, 1997; Pham \& Lai, 2016), we suggest that higher education institutions should pay more attention to the difference between expectation and actual performance of their higher education service (which constitutes disconfirmation) as well as satisfaction among their incumbent international students. Higher education providers should evaluate these factors frequently to obtain updated feedback from international students.

Second, this study revealed that value, rather than the two other factors (disconfirmation and satisfaction), is the most important predictor of loyalty. Among the three sub-constructs of value, which include attainment value, utility value and intrinsic value, we demonstrated that attainment value is the most important predictor. This implies that when a student decides to go abroad to seek a degree, he or she would expect to gain considerable value at the expense of his or her sacrifices; sacrifices including financial ones, time away, or distance from his or her family. Given this, it is suggested that higher education providers put value-adding strategies at the center of activities for international students. For instance, as international students often encounter language challenges (Sawir, 2005; Zhang \& Mi, 2010), universities may provide proofreading service to help them in their academic studies, and thus, add value for them in terms of the attainment dimension.

In addition, a number of measures are recommended to enhance utility value among international students. Degree equivalency is one of these. Anecdotal evidence has shown that despite the superiority of foreign degrees compared to those of Vietnam, Vietnamese authorities or recruiters still do not recognize the value of foreign diploma in certain circumstances. For instance, Kien Trung (2012) reported the case of a Vietnamese returnee whose diploma (from the University of Melbourne) did not get equivalent recognition from Vietnam's Ministry of Education and Training. This stemmed from the fact that this returnee undertook a coursework master's program in law, which was alien to the Vietnamese system, in which all master's students are required to write dissertations as a prerequisite condition for graduation. Given these arguments, higher education suppliers, including both 
universities and host countries, may want to promote credit transferability, and mutual recognition at the inter-governmental level. These efforts would no doubt bring more value for their international students in terms of the utility perspective.

Last but not least, enhancing intrinsic value, i.e., the degree of enjoyment for international students, should also be considered as a strategic measure for higher education suppliers. As Andrade (2006) argued, international students are also sojourners who not only stay at their campuses but also live in the host countries for an extended time. It is suggested that coordinating with universities to improve entertainment opportunities for international students during their sojourns overseas is essential for both parties.

\section{Limitations and Future Research}

The limitation of this study is the ignorance of cost in our conceptual framework. According to the expectancy-value model of achievement motivation (Battle \& Wigfield, 2003; Wigfield \& Eccles, 1989), cost is an important factor, juxtaposed to the concept of value. In the web-based learning setting, Chiu \& Wang (2008) defined cost as social isolation, anxiety, delay in responses and risk of arbitrary learning. According to Battle \& Wigfield (2003), "cost refers to what the individual has to give up to do a task, as well as the anticipated effort one will need to put into task completion" (p. 58). Given this limitation, future researchers may consider further incorporating cost into their study, as part of the general consideration of the cost of the scientific enterprise (Vuong, 2018).

Another limitation is that only the affective dimension of loyalty is considered. The behavioral dimension of loyalty, the continued intention to undertake further study, is overlooked in this study. Prospective researchers may include behavioral loyalty of international students in their studies, or alternatively, conceptualize student loyalty as a composite approach, i.e., incorporating both behavioral and attitudinal loyalty into one single construct.

\section{Acknowledgement}

We would like to thank Vuong Thu-Trang, Sciences Po, France for her excellent editing service.

\section{References}


Alves, H. (2011). The measurement of perceived value in higher education: A unidimensional approach. The Service Industries Journal, 31(12), 1943-1960.

Andrade, M. S. (2006). International students in English-speaking universities: Adjustment factors. Journal of Research in International Education, 5(2), 131-154.

Appleton-Knapp, S. L., \& Krentler, K. A. (2006). Measuring student expectations and their effects on satisfaction: The importance of managing student expectations. Journal of Marketing Education, 28(3), 254-264.

Athiyaman, A. (1997). Linking student satisfaction and service quality perceptions: the case of university education. European Journal of Marketing, 31(7), 528-540.

Backman, S. J., \& Crompton, J. L. (1991). Differentiating between High, Spurious, Latent, and Low Loyalty Participants in Two Leisure Activities. Journal of Park and Recreation Administration, 9(2), 1-17.

Battle, A., \& Wigfield, A. (2003). College women's value orientations toward family, career, and graduate school. Journal of Vocational Behavior, 62(1),56-75.

Bhattacherjee, A. (2001). Understanding Information Systems Continuance: An Expectation-Confirmation Model. MIS Quarterly, 25(3), 351-370.

Choudaha, R., \& Kono, Y. (2012). Beyond More of the Same: the top four emerging markets for international student recruitment. World Education News \& Reviews.

Chiu, C. M., \& Wang, E. T. (2008). Understanding Web-based learning continuance intention: The role of subjective task value. Information \& Management, 45(3), 194-201.

Chiu, C. M., Wang, E. T., Fang, Y. H., \& Huang, H. Y. (2014). Understanding customers' repeat purchase intentions in $\mathrm{B} 2 \mathrm{C}$ e-commerce: the roles of utilitarian value, hedonic value and perceived risk. Information Systems Journal, 24(1), 85-114.

Douglass, J. A., \& Edelstein, R. (2009). The global competition for talent: The Rapidly Changing Market for International Students and the Need for a Strategic Approach in the US. Center for Studies in Higher Education.

Eccles, J. S. (1987). Gender roles and women's achievement-related decisions. Psychology of Women Quarterly, 11(2), 135-172.

Edvardsson, B., Tronvoll, B., \& Gruber, T. (2011). Expanding understanding of service exchange and value co-creation: a social construction approach. Journal of the Academy of Marketing Science, 39 (2), 327-339.

Ehrenberg, R. G. (2012). American higher education in transition. The Journal of Economic Perspectives, 26(1), 193-216.

Field, A. M. (1999). The college student market segment: A comparative study of travel behaviors of international and domestic students at a southeastern university. Journal of Travel Research, 37(4), 375-381.

Floh, A., Zauner, A., Koller, M., \& Rusch, T. (2014). Customer segmentation using unobserved heterogeneity in the perceived-value-loyalty-intentions link. Journal of Business Research, 67(5), 974-982.

Gorges, J., \& Kandler, C. (2012). Adults' learning motivation: Expectancy of success, value, and the role of affective memories. Learning and Individual Differences, 22(5), 610-617.

Grönroos, C., \& Voima, P. (2013). Critical service logic: making sense of value creation and co-creation. Journal of the Academy of Marketing Science, 41(2), 133-150.

Ha, H. Y., \& Janda, S. (2008). An empirical test of a proposed customer satisfaction model in e-services. Journal of Services Marketing, 22(5), 399-408. 
Ha Phuong (2016). Vietnamese oversea students mostly stay in Japan. Retrieved from: http://vietnamnet.vn/vn/giao-duc/du-hoc/du-hoc-nhat-ban-du-hocmy-du-hoc-sinh-viet-nam-dong-nhat-o-nhat-337144.html

Healey, N. M. (2008). Is Higher Education in "Really" "Internationalising"? Higher Education: The International Journal of Higher Education and Educational Planning, 55(3), 333-355.

Hechanova-Alampay, R., Beehr, T. A., Christiansen, N. D., \& Van Horn, R. K. (2002). Adjustment and strain among domestic and international student sojourners a longitudinal study. School Psychology International, 23(4), 458-474.

Hu, T., Kettinger, W. J., \& Poston, R. S. (2015). The effect of online social value on satisfaction and continued use of social media. European Journal of Information Systems, 24(4), 391-410.

Jones, M. A., Reynolds, K. E., \& Arnold, M. J. (2006). Hedonic and utilitarian shopping value: Investigating differential effects on retail outcomes. Journal of Business Research, 59(9), 974-981.

Khawaja, N. G., \& Dempsey, J. (2008). A Comparison of International and Domestic Tertiary Students in Australia. Australian Journal of Guidance and Counselling, 18(01), 30-46.

Kim, H. W., \& Gupta, S. (2009). A comparison of purchase decision calculus between potential and repeat customers of an online store. Decision Support Systems, 47(4), 477-487.

Kumar, V., Dalla Pozza, I., \& Ganesh, J. (2013). Revisiting the satisfactionloyalty relationship: empirical generalizations and directions for future research. Journal of Retailing, 89(3), 246-262.

Marginson, S. (2007). Global position and position taking: The case of Australia. Journal of Studies in International Education, 11(1), 5-32.

Liao, C., Chen, J. L., \& Yen, D. C. (2007). Theory of planning behavior (TPB) and customer satisfaction in the continued use of e-service: An integrated model. Computers in Human Behavior, 23(6), 2804-2822.

Marginson, S., Tytler, R., Freeman, B., \& Roberts, K. (2013). STEM: country comparisons: international comparisons of science, technology, engineering and mathematics (STEM) education..

Oliver, R. L. (1980). A cognitive model of the antecedents and consequences of satisfaction decisions. Journal of Marketing Research, 460-469.

Pandža Bajs, I. (2015). Tourist perceived value, relationship to satisfaction, and behavioral intentions: The example of the Croatian tourist destination Dubrovnik. Journal of Travel Research, 54(1), 122-134.

Parasuraman, A., \& Grewal, D. (2000). The impact of technology on the quality-value-loyalty chain: a research agenda. Journal of the Academy of Marketing Science, 28(1), 168-174.

Pham, H. H., \& Lai, S. L. (2016). Higher Education as an Extended Duration Service: An Investigation of the Determinants of Vietnamese Overseas Student Loyalty. Journal of Studies in International Education, 20(5), 454-471.

Ravald, A., \& Grönroos, C. (1996). The value concept and relationship marketing. European Journal of Marketing, 30(2), 19-30.

Reichheld, F. F. (2003). The One Number You Need to Grow. Harvard Business Review, 81 (12), 2-10.

Sawir, E. (2005). Language difficulties of international students in Australia: The effects of prior learning experience. International Education Journal, 6(5), 567580 . 
Slaughter, S., \& Cantwell, B. (2012). Transatlantic moves to the market: The United States and the European Union. Higher Education, 63(5), 583-606.

Sweeney, J. C., \& Soutar, G. N. (2001). Consumer perceived value: The development of a multiple item scale. Journal of Retailing, 77(2), 203-220.

University Australia (2016, November, 21). International education generates a record \$20.3 billion for Australia. Retrieved from URL: https://www.universitiesaustralia.edu.au/Media-and-Events/mediareleases/International-education-generates-a-record--20-3-billion-forAustralia\#.Wdy $1 \mathrm{KmKCzC8}$

Varas, J. (2016, April, 5). The native-born STEM shortage. American Action Forum. Retrieved from: https://www.americanactionforum.org/research/native-bornstem-shortage/

Vuong, Q. H. (2017) Open data, open review and open dialogue in making social sciences plausible. Nature: Scientific Data Updates. Retrieved from URL: $<\underline{\text { http://blogs.nature.com/scientificdata/2017/12/12/authors-corner-open-data-open- }}$ review-and-open-dialogue-in-making-social-sciences-plausible/>

Vuong, Q. H. (2018) "The (ir)rational consideration of the cost of science in transition economies". Nature Human Behaviour 2(1), 1. Retrieved from URL (DOI): https://doi.org/10.1038/s41562-017-0281-4.

Wigfield, A., \& Eccles, J. S. (1989). Relations of expectancies and values to students' math grades and intentions. In Meeting of the American Educational Research Association, San Francisco.

Zhang, Y., \& Mi, Y. (2010). Another look at the language difficulties of international students. Journal of Studies in International Education, 14(4), 371-388. 